\title{
Império e educação: rupturas e continuidades no processo educacional brasileiro durante o primeiro reinado (1822-1836)
}

\author{
Maria Elizete Guimarães Carvalho
}

\begin{abstract}
Resumo
O estudo reflete sobre o processo educacional brasileiro durante o Primeiro Reinado, período marcado por rupturas e continuidades, pela centralização/descentralização política e pela ausência de escolas. Com o propósito de construir novas leituras e representações desse momento histórico, articula-se acontecimentos, legislação e educação, trazendo configurações de um tempo/espaço marcante da história da educação brasileira. Ora, em uma sociedade colonial como a brasileira, inexistiam exigências educacionais originadas na economia, encontrando na Europa sua orientação. Assim, a educação processada durante o Império articulava-se com as necessidades da sociedade, marcada por aspectos de continuidade e rupturas presentes na vida e na educação. Nesse cenário, precedido de lutas abortadas, mas que imprimiram sua marca, de disputas políticas, qual o significado e o lugar da educação? A ausência de escolas para o povo, o dualismo educacional, a defasagem entre a letra da lei e sua prática revelam os interesses da sociedade brasileira no Primeiro Reinado. O estudo utilizou-se de fontes documentais escritas e iconográficas, em um tratamento metodológico de articulação, complementação e interpretação de leis, textos e pinturas históricas.
\end{abstract}

Palavras-chave: processo educacional, rupturas, continuidades.

\section{Impire and education: ruptures and continuities in the brasilian educational process while the first reign}

(1822-1836)

\begin{abstract}
The study ponders about the brazilian educational process while the First Reign, period marked by ruptures, continuities, politic centralization/decentralization and absence of schools. With the intention of building new lectures and representations of this historic moment, are linked events, legislation and education, bringing configurations of a marking time/space of the brazilian history. Well, in a colonial society like the brazilian one there weren't educational exigencies originated of the economy, finding in the Europe its orientation. So, the processed education, while the Reign, linked with the necessities of the society marked by aspects of continuity and ruptures present in the life and in the education. In this scenery, preceded by aborted fights, but impressed its mark, politic disputes, what does mean education and where is its place? The absence of schools to the people, the educational dualism, the discrepancy between the letter and the law and its practice show the interests of the brazilian society in the First Reign. The study used documental, writing and iconographic sources, in an articulation metodologic treatment, complementation and interpretation of laws, texts and historic paintings.
\end{abstract}

Key-words: educational process, ruptures, continuities. 
O processo educacional brasileiro desenvolvido nas primeiras décadas do Império configura-se como caótico e precário. Primeiro pelo fato desse período apresentar-se marcado por rupturas e continuidades no contexto histórico e educacional; e segundo, pela centralização/descentralização política e pela ausência de escolas. Esse cenário em formação há algum tempo, passou por importantes transformações com a chegada da família real, o que vai contribuir para a ruptura do pacto colonial e para o aprofundamento de alterações internas, configurando-se uma trajetória em direção à Independência.

Ora a estrutura social do Brasil-Colônia aponta para a continuidade das relações sociais existentes, caracterizadas pela submissão externa e interna, enfatizadas pela autonomia política realizada a partir de acordos entre a classe dominante colonial, outros segmentos sociais e a burguesia européia. Em consequência, a estrutura de poder e de dominação continua igual, apesar da Independência. A classe dominante empreende a Independência, mas não se contradiz em seus interesses. Os acordos realizados não implicam em rupturas com a situação anterior.

Ante o aspecto da continuidade, reflita-se sobre o da ruptura. Em um cenário de dominação e submissão, havia espaço para a contradição? Ora a placidez era apenas aparente. As condições históricas para a contradição foram sendo formadas motivando descontentamentos, conflitos e lutas internas que orientavam para a Independência. Porém, a ruptura é resultante da "conjugação de interesses internos e externos à sociedade brasileira, decorrendo daí as próprias limitações" (RIBEIRO, 1993, p. 39), implicando que ruptura e continuidade estarão desde sempre imbricadas.

Vale lembrar, nesse momento, que a sociedade brasileira já havia vivenciado a experiência educacional jesuítica, experienciando o sistema de Aulas Régias, que permaneceu inalterado no Brasil até o Primeiro Reinado.

Tendo em vista esse contexto, precedido de lutas abortadas, mas que imprimiram sua marca, de disputas políticas, em que o movimento da independência aconteceu de cima para baixo, como se processaria a educação? Qual o significado e o espaço que ocuparia? Com o propósito de construir novas leituras e representações desse momento histórico, produziu-se uma discussão que articula acontecimentos, legislação e educação, trazendo configurações de um tempo/espaço marcante da história da educação brasileira.

A proposta de novas leituras sobre o período está relacionada a um projeto em desenvolvimento nomeado Educação Brasileira: da Colônia às Primeiras Décadas do Império (1549-1836). Trata-se de uma investigação que teve origem na práxis docente, na constatação da urgente necessidade de criar um banco de dados (entre textos legais, teóricos e iconográficos) para subsidiar o trabalho com a disciplina História da Educação. A articulação, complementação e interpretação dos textos selecionados propiciariam sua releitura e a produção de outros tecidos textuais que complementariam e contribuiriam para a docência e literatura científica desse campo do conhecimento. A carência/limitação de textos ou de abordagens sobre alguns períodos dificulta o intercâmbio entre passado e presente, função social da História, compreendendo-se ser imprescindível um trabalho constante de reinterpretação do passado, tendo em vista às demandas do presente e à projeção imaginária do futuro. É como afirmam Cardoso e Brignoli (1990, p. 479): "Tanto Marx quanto Febvre e Bloch acreditavam que não se pode compreender o passado fechando-se a seu próprio tempo."

Nesse contexto, foi produzido o presente trabalho. Tomando como fundamento um olhar que harmoniza presente e passado, as fontes foram trabalhadas, articulando-se texto e contexto, em um esforço reflexivo para recuperação e ampliação de significados e representações, apostando-se na diversidade textual para reler o passado, na tentativa de "reconstruir uma escrita da história 'a contrapelo' (MARTINS, 2009, p. 288).

O redirecionamento do olhar para outros textos trouxeram a pintura histórica como desafio para o trabalho. "A História faz-se com textos", afirmou Febvre em 1934, ampliando a concepção de documento histórico: “[...] E não só os documentos de arquivos em cujo favor se cria um privilégio. [...] 
Mas, também, um poema, um quadro, um drama: documentos para nós, testemunhos de uma história viva e humana, saturada de pensamento e de ação em potência" (FEBVRE, 1977, p. 20-21).

Assim, foram questões relacionadas à docência e a preocupações históricas que motivaram esse estudo. Pois o cenário atual aponta para a urgência de reelaboração do passado, o que torna imprescindível o intercâmbio de experiências, a recriação de fatos e acontecimentos, cabendo ao pesquisador buscar na memória histórica as razões, o tecido que explicam o presente.

Utilizando-se de fontes documentais escritas, como estudos teóricos, legislação, crônicas; e iconográfica, como pintura histórica, esse estudo pretende refletir e analisar a educação brasileira nas rupturas e continuidades, considerando o cenário histórico que as produziu.

\section{Rupturas e Continuidades no Processo Educacional Brasileiro nas Primeiras Décadas do Império}

A compreensão do processo educacional brasileiro desenvolvido nas primeiras décadas da constituição do Império exige preliminarmente uma análise do cenário histórico que originou tal processo, afirmando-se que a autonomia conquistada não representou a emancipação do povo brasileiro do domínio do colonizador português, considerando as condições históricas em que se realizou, pelo fato de não ter sido resultante das alterações internas que se processavam na Colônia.

Nesse sentido, é necessário refletir sobre o significado da autonomia e da ruptura resultantes da Independência brasileira conseguida em 7 de setembro de 1822. Inicialmente, o novo período da história do Brasil rompe com os laços coloniais e instaura uma nação soberana. Porém, grande contra-senso e ambigüidade: no poder central do novo país estava o herdeiro do trono português. Como então compreender um processo emancipador que desconsiderou as necessidades internas e os anseios de um povo? Há de lembrar que a colônia passava por transfor- mações resultantes das próprias condições internas e sentia a influência externa, apesar da forte proibição da entrada de novas idéias, como é o caso do projeto educacional imodificável por mais de 200 anos. Esse fato não impede, no entanto que os ecos dos movimentos e correntes de idéias que se processavam lá fora não aportassem no Brasil. É preciso considerar que a elite colonial brasileira complementava sua educação com uma viagem de estudos à Europa, fato que os fazia conviver e vivenciar as transformações que estavam ocorrendo fora do Brasil.

Mais tarde, a abertura econômica, propiciada pela abertura dos portos, contribuirá para a entrada de ideologias, que entre outras marcará o momento histórico, a ideologia liberal, responsável pelos embates contra as práticas autoritárias e absolutistas.

Ora, uma Independência sem a participação do povo implica em uma compreensão que destoa dos acontecimentos. Na verdade, o sistema colonial estava em crise. As revoltas ocorridas já eram uma prova desse fato. Os movimentos Inconfidência Mineira (1789) e Conjuração Baiana (1798) são movimentos emancipatórios precursores da Independência. As idéias iluministas que circulavam na Europa e que deram causa à Revolução Francesa e à Revolução Americana estavam circunscritas no ideário da elite intelectual brasileira. Como então olvidar esses fatos e reconhecer uma Independência resultante de acordos e que não correspondeu/respondeu às tensões e alterações internas? A tomada de consciência do povo brasileiro era um processo que se desenvolvia e vinha à tona, refletindo a crise do sistema colonial. Nesse espaço, coloca-se para reflexão o quadro Independência ou Morte do pintor Pedro Américo, que embora tente expressar uma suposta harmonia através das cores, acabamento, termina revelando o que não quis/não podia expressar. Uma Independência fabricada. A perfeição do quadro que destoa da realidade dos fatos abre espaço para uma interpretação que se articula com outros textos que mostram as tensões e os interesses em desenvolvimento no período.

Os movimentos, de caráter emancipacionista, refletem, no plano político, o agravamento das tensões derivadas do próprio funcionamento do 
sistema colonial, e por aí se inserem no quadro geral da revolução no Ocidente. O exemplo secessionista da América inglesa esteve permanentemente vivo em todo o processo da rebelião mineira; "o espectro libertário da França revolucionária acompanha os insurretos baianos de 1798, que, para além da emancipação, chegaram a visar 'uma inteira revolução', de que resultaria uma nova ordem sem diferença de cor branca, preta ou parda" (NOVAIS, 1986, p. 57).

Assim, as transformações que ocorriam em sociedades ocidentais repercutiam-se na América portuguesa, o que apontava para outras formas políticas de organização e administração do Estado, tornando-se premente a necessidade de organizar um Estado que mantivesse a unidade territorial e considerasse os anseios da população. Tais mudanças foram desconsideradas no ato político da Independência, vencendo a proposta de apoio a dom Pedro, com a instalação de uma monarquia, sem a participação popular, o que era temerário, devido ao fato de tal participação poder resultar em agitações e conquista do poder pelos grupos republicanos. Daí resultar a opção da independência brasileira ser realizada pelo próprio colonizador, fato com conseqüências para a autonomia do país, que se tornaria dependente da Inglaterra.

Por outro lado, falar em ruptura também é um discurso que se compreende irrelevante, por razões implícitas no próprio processo de independência. Ora, tal independência significou, como anunciado anteriormente, um acordo, ou seja, a vitória do grupo conservador, dos moderados, constituído pelos grandes proprietários de terra, defensores da manutenção do escravismo, bem como de liberais conservadores, sem falar que o príncipe, proclamador da independência era o próprio colonizador. É de perceber, então, que a situação brasileira distanciava-se em muitos sentidos da Europa, pois enquanto nesta o liberalismo caminhava a passos largos para a industrialização, no Brasil a reforma política não propiciou mudanças econômicas e sociais significativas. No Brasil, predominou muito mais as características da continuidade do que os aspectos da ruptura. Percebe-se que as estruturas sociais anteriores à independência, desde a escravidão até o comando do Estado por um imperador, apontam para a continuidade, significando um novo cenário vestido de velho.

Cabe explicar tal fato com as palavras de Sergio Buarque de Holanda: a democracia no Brasil foi sempre um lamentável mal-entendido. Uma aristocracia rural e semifeudal importou-a e tratou de acomodá-la, onde fosse possível, aos seus direitos ou privilégios, os mesmos privilégios que tinham sido, no Velho Mundo, "o alvo da luta da burguesia contra os aristocratas. E assim puderam incorporar à situação tradicional, ao menos como fachada ou decoração externa, alguns lemas que pareciam os mais acertados para a época e eram exaltados nos livros e discursos" (HOLANDA, 1991, p. 119-120).

Nesse cenário, a sociedade brasileira, de base escravocrata, era constituída por uma elite colonial e por escravos, em que se cruzavam brancos, negros, pardos e índios, o que autoriza a afirmação de que a clientela escolar se reduzia aos filhos dos "homens livres", lembrando que a elite colonial mantinha preceptores para a educação de seus filhos.

\section{Independência e Educação: o processo educacional brasileiro durante o Primeiro Reinado}

Com a transferência da família real portuguesa para o Brasil no início do século XIX, fugindo ao ataque do exército napoleônico, em um momento em que as transformações notadamente econômicas e políticas colocavam a Inglaterra e a França no epicentro da hegemonia mundial, a colônia brasileira vivenciou importantes modificações, que desencadearam o desenvolvimento de um processo emancipatório que culminaria com a independência. Tal processo incluiu medidas transformadoras, como a abertura dos portos ao comércio exterior, a revogação do alvará que proibia a instalação de manufaturas, significando de certa forma a ruptura do pacto colonial. Nesse sentido, também pode ser compreendida a criação de várias instituições de ensino superior, haja vista os cursos superiores 
na Academia Real da Marinha (1808), Academia Real Militar (1810), Academia médico-cirúrgica da Bahia (1808) e Academia médico-cirúrgica do Rio de Janeiro, com o propósito de formar quadros para o suprimento da nova situação que se criava na Colônia.

Considerando essa nova realidade, em um país escravocrata e monocultor, o príncipe-regente realiza as adaptações necessárias para a instauração e funcionamento do seu governo. Assim, reestrutura o plano político, o econômico, o jurídico e o cultural, realizando modificações, que apesar de destoarem da realidade da Colônia e contemplarem apenas a elite dirigente, vão contribuir para a formação de um novo contexto.

Pelo visto, nesse momento, não havia uma política educacional sistemática e planejada. É como afirma Aranha (2006), referindo-se às mudanças que tendiam a resolver problemas imediatos, sem encará-los como um todo. "Quando a família real chegou ao Brasil, existiam as aulas régias do tempo de Pombal, o que obrigou o rei a criar escolas, sobretudo superiores, a fim de atender às necessidades do momento" (ARANHA, 2006, p 221).

Assim, as preocupações educacionais estavam relacionadas com a permanência da família real e com a administração da Colônia. No que se referia ao povo em geral, uma medida que poderia contribuir para sua instrução foi a permissão de abertura de escolas de primeiras letras, a qualquer pessoa, que em sua maioria funcionavam na própria casa do professor. Para as elites, a preocupação concentrava-se na criação de cursos superiores, pois estas recebiam os preceptores em suas casas para as noções elementares das primeiras letras.

É importante lembrar que nesse momento, o Brasil já tinha vivenciado o período jesuítico educacional (1549-1759), que embora marcado pela gratuidade, era voltado para os filhos das elites dominantes, excluindo a população escrava, os desprovidos de posses e as mulheres, mas incluía os índios nos aspectos catequético e missionário, contemplados pela "missão colonizadora".

Com a expulsão dos jesuítas, no período seguinte, o das Reformas Pombalinas, ocorre o desmantela- mento de uma estrutura administrativa escolar baseada na educação religiosa jesuítica. Tal sistema educacional dispunha de uma estrutura institucional edificada em todo o litoral latifundiário, com ramificações pelas matas e pelo planalto, e cujos colégios e seminários foram os grandes focos de irradiação da cultura. Essa organização contribuía para a unidade social e cultural da Colônia.

Por que então a expulsão dos jesuítas? Ora nesse período, vivenciava-se o mito da modernidade em relação ao que era considerado velho, ao passado. E embora o Estado Português tivesse sido pioneiro no contexto mercantilista, encontrava-se defasado em relação a outras potências européias, tanto econômica, política como culturalmente. Aos jesuítas então foi atribuída a responsabilidade pelo atraso econômico, político e cultural português. No discurso legal pombalino, os jesuítas representavam um passado a ser repudiado e descartado: “[...] os discípulos de Inácio de Loyola constituíam uma interrupção do fluxo natural da história da nação portuguesa, uma vez que estavam muito mais subordinados ao Vaticano do que ao Estado português". (OLIVEIRA, 2010, p. 24).

Em verdade, Portugal precisava recuperar o tempo perdido, sair do atraso econômico e acelerar o desenvolvimento capitalista. Porém eram divergentes os interesses de Portugal e da Companhia de Jesus. Os privilégios e regalias gozados pelos jesuítas incomodavam ou travavam a economia portuguesa.

Desse modo, o anti-jesuitismo do discurso da legislação pombalina tem caráter muito mais político e econômico do que ideológico, pois a Companhia de Jesus representava um obstáculo para a implementação e desenvolvimento das novas diretrizes da administração colonial, que, por sua vez, buscava a todo custo colocar o Estado português em condições políticas e econômicas que lhe permitissem competir com as demais nações européias. A sua expulsão definitiva, no entanto, deveu-se a sua reação ao Tratado de Madri, de 
1750, atitude que tornou inviável qualquer possibilidade de acordo ou solução pacífica (OLIVEIRA, 2010, p. 27).

Pelo visto, não foi o atraso do método ou a orientação pedagógica que determinaram a expulsão jesuítica de Portugal e de suas colônias.

Assim, uma longa tradição pedagógica de quase dois séculos foi atacada ferozmente, sendo destruída toda organização educacional existente no Brasil. As reformas pombalinas substituíram o sistema jesuítico de educação por aulas isoladas de matérias, fragmentárias e dispersas. Porém, vale salientar, que o espírito continuava o mesmo e iguais também as orientações pedagógicas: métodos, sistema disciplinar, sob a orientação da Igreja e da aristocracia agrária. O ensino continuava dirigido a uma clientela proveniente das elites rural e burguesa e poucos eram os mestiços que conseguiam furar esse sistema tradicional.

Assim, o reformismo pombalino, que desejava colocar Portugal em sintonia com as modernas nações européias, tentou eliminar o jesuitismo e sua base intelectual, o Ratio Studiorum, instituindo em seu lugar as Aulas Régias. Nesse cenário, o Estado português estatizou o ensino, organizando um sistema determinado e controlado pelo Estado, não mais mantido pelo Estado e voltado para os interesses da Igreja, como anteriormente, embora a laicização admitisse a obrigatoriedade da religião católica.

Ora, é de perceber que as próprias condições internas da Colônia seriam obstáculos para a incorporação do Brasil na modernidade pós-renascentista. Faltavam condições materiais ao Estado para a substituição dos colégios jesuítas; afinal tinham sido 200 anos de estruturação. Por outro lado, a abertura às novas idéias tinha caráter limitado. Não se admitiam as idéias políticas de Montesquieu, Voltaire, Rousseau, Diderot, mas sim a leitura de Galileu, Descartes, Newton, entre outros, que não questionavam o poder constituído.

Nesse sentido, apesar da Reforma pombalina, que pretendia colocar Portugal em posição de igualdade frente às nações modernas da Europa, que já vivenciavam as concepções hobbesiano-hegelianas, que colocavam em discussão as estruturas política e social anteriores, como também o paradigma newtoniano na forma de abordagem da realidade, o mundo ibero-americano conservava elementos e aspectos do universo tridentino, o que o mantinha em uma posição diferenciada e tradicional. Então, para efetivar a modernização do Estado português, a influência da Igreja necessitava ser amenizada.

Os ideais de cultura, civilização, progresso e educação da humanidade que nortearam a Ilustração criaram a necessidade de se atenuar a influência da Igreja sobre a sociedade da época, em prol da modernização e da centralização política do Estado português, ainda que as reformas empreendidas por Pombal tenham tentado 'conduzir numa harmonia de interesses, conjuntamente, a República e a Igreja pelo caminho do progresso, material e espiritual da nação lusitana' (CARDOSO, 2010, p. 205).

É assim que a reforma não se constituiu uma ruptura total com a tradição religiosa, apesar de criar-se, sob o ministério do Marquês de Pombal, um ensino público financiado pelo Estado e para atender suas necessidades, pela publicação do Alvará de 28-6-1759. Tal Alvará, entre outras disposições, criava o cargo de diretor geral dos estudos, determinava a "prestação de exames para todos os professores, que passaram a gozar do direito de nobres, proibia o ensino público ou particular sem licença do diretor geral dos estudos e designava comissários para o levantamento sobre o estado das escolas e professores" (RIBEIRO, 1993, p. 33).

Para melhor compreensão do sentido da política educacional do governo de D. José I, considere-se a afirmação de Cardoso (2010):

O que se pode dizer, em linhas gerais, é que, em termos de política educacional, o governo de D. José I, [...] organizou o sistema de ensino de modo a fazer dos 
professores e funcionários da Coroa portuguesa ferramentas de controle social, político e cultural. Tais professores e funcionários, por sua vez, seriam controlados por outros funcionários e censores que ocupavam cargos de confiança, o que centralizaria o poder do déspota, ajudando-lhe a concretizar seu plano de governo (CARDOSO, 2010, p. 207).

A reforma caracterizava o ensino como Estudos Menores e Estudos maiores. Os estudos Menores compreendiam as Aulas de ler, escrever e contar, também chamadas de primeiras letras e também as Aulas de Humanidades, que correspondiam ao ensino secundário. Concluídos esses estudos, o aluno estava preparado para cursar os Estudos Maiores, ou seja, a universidade.

Na verdade, não obstante a utilização de novos métodos, novos livros, o ensino secundário passou a ser organizado sob a forma de aulas avulsas ou aulas régias, o que pedagogicamente significava um retrocesso na organização educacional. As aulas de humanidades compreendiam inicialmente as cadeiras de gramática latina, língua grega, língua hebraica, retórica e poética, que futuramente ganharam novas cadeiras como filosofia moral e racional.

Merece registro o fato de que não havia continuidade entre os níveis de estudo, valendo ressaltar, também o fato de que a escola pública nunca preencheu as necessidades da população.

O sistema de Aulas Régias permaneceu inalterado no Brasil até o Primeiro Reinado, devendo ser compreendido tanto como imposição, pois se tratava de um projeto de dominação estabelecido pelo governo português, como também um avanço, já que manifestava o compromisso com as idéias da Revolução Científica e da Ilustração. Esses novos referenciais estavam de acordo com as perspectivas de seu tempo, porém em desacordo com as formas conservadoras de dominação. Daí a Reforma, colocada de cima para baixo, não atender às necessidades imediatas da população colonial.

Quando D. João VI chega ao Brasil em 1808, é essa a situação educacional encontrada. Em virtude desse quadro e das necessidades administrativas do governo imperial, são criados vários cursos superiores, que na verdade vão atender à elite colonial e portuguesa, mas que já surgem das necessidades internas do contexto histórico, embora tais necessidades tenham passado a existir com a mudança do Brasil para sede do reino português.

Quanto aos outros níveis de ensino, a escola de primeiras letras, ou seja, a escola de ler, escrever e contar, ganha notoriedade, devendo-se essa importância ao desejo dos indivíduos de preparação para o ingresso nos pequenos cargos burocráticos criados naquele momento, como também a preparação para o curso secundário, não implicando, no entanto, que aquela fosse condição para o acesso a tal curso. Mas devido à instrumentalização técnica desse nível, que ganha em credibilidade, mais de 60 cadeiras de primeiras letras são criadas, em atendimento às próprias necessidades do momento histórico.

Já o curso secundário permanece organizado em aulas régias, tendo-se notícia da criação de pelo menos umas 20 cadeiras de gramática latina, entre cadeiras de matemática, desenho, história, retórica, filosofia, inglês e francês criadas em diversos locais da Colônia.

Todavia, merece esclarecimento a estrutura social do Brasil-Colônia. Havia uma predominância da submissão não só externa, mas também a nível interno, desenvolvendo-se um clima de profunda opressão, não favorecendo espaço para manifestações de descontentamento ou insatisfação. A submissão que marcava as relações sociais na Colônia manifestava-se externamente em relação à metrópole, de modo interno, no que diz respeito à maioria negra ou mestiça pela minoria branca. Tal submissão interna refletia-se "não só nas relações de trabalho como também nas relações familiares, como lembra Gilberto Freire: da esposa em relação ao marido, dos filhos em relação ao pai” (RIBEIRO, 1993, p. 37).

Esse fato não significa afirmar que não houvesse contradições internas. Estas manifestavam-se em lutas, em episódios violentos, motins, atentados, rebeliões, que expressavam o desejo de libertação dos explorados frente à repressão brutal da Metrópole. 


\section{Primeiro Reinado e Educação: legislação e ensino}

O processo emancipatório brasileiro, construído a partir do conjunto de contradições externas e internas, vai culminar com a autonomia política em 1822, que na verdade é resultante da união da classe dominante colonial, com o apoio de outras camadas da sociedade, configurando-se o Império a representação da classe que empreendeu a Independência. Assim, a nação que exsurge vai confirmar os elementos de continuidade e conservação, afirmando o regime monárquico, o que aponta para uma ruptura aparente com as formas coloniais de dominação. A Independência tem como base acordos políticos de interesse da classe dominante, formada pela camada senhorial brasileira, em sintonia com o capitalismo europeu. Daí não representar uma ruptura, já que não é conseqüência imediata das lutas pela emancipação.

Com o nascimento de um novo Estado, fazia-se necessário uma Constituição. A Assembléia Constituinte instalada após a Independência (1823) para gestar o texto Constitucional inspirava-se na Constituição Francesa de 1791, que embora de cunho liberal, orientaria a Carta Magna do Estado Monárquico. Dissolvida a Assembléia Constituinte, a Carta Constitucional, outorgada em 1824, trazia exigências quanto à organização educacional do país, abandonando, no entanto, a idéia de um sistema nacional de educação presente no projeto de lei gestado pela Assembléia, em que se manifestava o propósito de imprimir unidade orgânica à instrução pública.

Ora, é necessário compreender a Constituição de 1824 em seu contexto histórico. Apesar do aparato liberal como forma exterior, a Lex Fundamentalis vai expressar os interesses dos grupos dominantes conservadores, além do mais, a educação constitui-se matéria de competência do Poder Moderador, e não da Assembléia Geral, que na disposição do artigo 98 da Lei Maior, é considerado como a "chave de toda a organização política” do Império. Esse aspecto revela a disposição centralizadora do Estado brasileiro, processada política e culturalmente desde o regime de Capitanias Hereditárias.
Assim, a educação ganha espaço na Constituição de 1824, nos incisos XXXII e XXXIII do artigo 179, que disciplina "A inviolabilidade dos Direitos Civis, e Políticos dos Cidadãos Brasileiros, que tem por base a liberdade, a segurança individual, e a propriedade, é garantida pela Constituição do Império", que entre outras formas aponta "A Instrução primária, e gratuita a todos os Cidadãos (inc. XXXII.) e "Colégios, e Universidades, aonde serão ensinados os elementos das Ciências, Bellas Letras, e Artes" (inc. XXXIII) (MARTINS, 2007, p. 4).

Percebe-se na disposição do inciso XXXII, artigo 179 da Constituição de 1824, a disposição liberal que o orienta, quando coloca a gratuidade da instrução primária estendida a todos os cidadãos em conformidade com as idéias e acontecimentos que vêm marcando o mundo, que propagam por um ensino público, gratuito e sob a responsabilidade do Estado. Já a disposição do inciso XXXIII tem cunho elitista e humanista.

Outro ponto que vale esclarecer diz respeito aos fatores impeditivos de uma rede eficiente de escolas, que colocasse em funcionamento as escolas primárias nas províncias. Ora, é patente a falta de recursos do Estado Imperial para esse propósito, como também é marcante o pouco ou nenhum interesse educacional e cultural das elites provinciais ou regionais pela educação.

Nesse contexto, já em 1827, foi aprovada a primeira lei nacional brasileira que tratava da instrução pública de nível elementar. Tal lei disciplinava a criação de escolas de primeiras letras, em todas as cidades, vilas e lugarejos, e ainda determinava a criação de escolas de meninas nas cidades e vilas mais populosas.

As idéias que orientavam essa lei estavam presentes no projeto de Januário da Cunha Barbosa (1826), e promoviam o ideal do ensino para todos como um dever do Estado, ampliando o ensino para todos os níveis ou graus. Pelo visto, a lei de 1827 passou longe das intenções do projeto, limitando a um único grau de ensino e seus objetivos: primeiras letras. Com tão grande limitação, o texto legal nem implicitamente fazia menção a um plano nacional de educação. 
Ora, para a elite esse fato não tinha grande importância, já que os graus de estudo não se constituíam em pré-requisitos uns para os outros, continuando como de costume anteriormente a educar seus filhos em casa, ou de outra forma, reuniam-se os pais e contratavam professores para ministrarem aulas em conjunto para seus filhos, não implicando nenhuma forma de vínculo com o Estado.

Já para os demais segmentos sociais, a limitação legal gerava implicações e conseqüências lamentáveis, pois, além da restrição do número de escolas, o que diminuía a oferta, a instrução limitava-se à elementar, ou seja, ler, escrever e contar.

Nesse sentido, é de reconhecer o descaso do poder público no cumprimento de suas obrigações, no provimento dos recursos materiais, no que dizia respeito aos estabelecimentos, livros didáticos, entre outros. "Também os baixos salários dos professores; a excessiva complexidade dos conhecimentos exigidos pela lei e que dificultava o provimento de professores; e a inadequação do método adotado em vista das condições particulares do país". (NASCIMENTO, 2009, 03).

Pelo exposto, a primeira Lei que tratava da instrução pública no país foi mais uma normatização não posta em prática, com suas intenções abortadas, por não estar em consonância com os interesses que se processavam no momento. Ora, o interesse pela instrução popular encontrava dificuldades não apenas nas condições reais do país, mas também esbarrava na suposta preocupação do governo com tal instrução, que ao mesmo tempo em que propalava essa necessidade, não disponibilizava os recursos para que as providências fossem tomadas.

Desse modo, retoma-se o ponto inicial dessa discussão: o modo de conquista da autonomia política do país. Se tal autonomia tivesse resultado do processo imediato das alterações internas que estavam ocorrendo na Colônia, as condições estariam postas para a organização educacional e as resistências e obstáculos seriam superados naturalmente.

As opções monárquica e conservadora da sociedade vão refletir nas decisões que beneficiariam a maioria da população, como se configuram as dificuldades para implantação de uma rede escolar de atendimento a toda população. A letra da lei vai revelar tal realidade, limitando a instrução ao nível elementar.

Nesse espaço, é necessário lembrar a questão econômica que subsidiava a manutenção da sociedade brasileira. As dificuldades eram tamanhas, afetadas pela falta de recursos, de um aparelho administrativo moderno, e as medidas tomadas para minorar a situação vão afetar toda a população. Tais medidas como taxações e empréstimos ao estrangeiro em pouco tempo instauram a crise econômica, refletindo-se em perturbações sociais e movimentos. Essa carência de recursos vai manifestar-se também nas disposições educacionais. Ora, se faltavam recursos para o provimento do aparelho estatal, não haverá disponibilidade para a reorganização da instrução pública.

Outro aspecto importante da orientação educacional desse período diz respeito à marginalização do ensino normal e técnico profissional pelo poder público. Tal fato pode ser explicado quando se recorda a clientela que estudava na época, ou seja, a elite para quem a escola era projetada, não manifestava interesse por esses cursos, já que não eram passaportes para o ensino superior.

Porém, a situação educacional vai se alterar com a instauração da orientação descentralizadora, ocorrida após a abdicação de dom Pedro I ao trono brasileiro, em 07/04/1831, disposta no único Ato Adicional à Constituição do Império, aprovado pela Lei $\mathrm{n}^{\circ} 16$, de 12 de agosto de 1834.

O Ato Adicional instituiu mudanças significativas. Criou as Assembléias Provinciais a quem atribuiu poderes para legislar sobre temas privativos do governo central, como economia, justiça, educação. Pelas proposições contidas no Ato Adicional de 1834, os liberais ganharam espaço para definirem os negócios públicos das províncias e transformá-los em atos jurídicos. Ora, a Lei de 1834 expressamente declara a descentralização da sanção da lei provincial, quando dispõe que as normatizações e resoluções das Assembléias Legislativas Provinciais que tratem de matérias abordadas nos artigos 10 e 11, receberão a sanção do Presidente da Província. Tal determinação invalidava o artigo 84 da Constituição de 1824, que 
determinava a remessa das resoluções dos Conselhos Gerais de Província ao Poder Executivo, por intermédio do Presidente da Província. Não estando a Assembléia Geral reunida no momento do envio das resoluções provinciais, ao Imperador caberá executá-las provisoriamente, se compreendê-las dignas e promissoras do bem geral da Província.

Registra-se aqui a importância da única Emenda à Constituição de 1824. A discussão entre centralização e descentralização no Brasil imperial. A descentralização na verdade foi apenas aparente, ou melhor dizendo, apresentava uma profunda ambivalência, pois ao mesmo tempo em que dispunha competências às Assembléias Provinciais, contribuiu para a recentralização do poder imperial. $\mathrm{Na}$ verdade, o Ato Adicional contribuiu para impedir a descentralização do poder político no Brasil.

Assim, no âmbito da descentralização, estava disciplinada a instrução pública, ficando determinado que às Assembléias Provinciais caberia legislar sobre instrução pública e estabelecimentos próprios a promovê-la, excetuando-se dessa competência, as faculdades de medicina, cursos jurídicos, academias existentes e outros estabelecimentos de instrução que futuramente fossem criados por lei geral.

Pelo visto, a descentralização da instrução pública dizia respeito apenas aos níveis elementar e secundário e à criação de estabelecimentos próprios, pois ao governo central caberia legislar sobre o ensino superior, monopólio que configura a intenção de orientação das camadas dirigentes da sociedade.

A descentralização foi prejudicial à criação de uma unidade orgânica do sistema educacional a partir do momento que determinou essa iniciativa às Províncias, com suas já precárias condições. A orientação que resultou do Ato Adicional contribuiu ainda mais para agravar a situação educacional e aprofundar as diferenças entre as classes. As Províncias precariamente ficariam responsáveis pela educação do povo e o poder central teria a obrigação pela educação da elite.

Ao lado do fracasso do ensino primário, o ensino secundário público também não alcançou êxito, acabando por ser assumido pela iniciativa privada, o que vem a intensificar o caráter classista e aca- dêmico do ensino, pelo fato de tornar-se privilégio das altas camadas da sociedade.

Assim, entre os dois níveis de ensino não existia articulação ou unidade de ações. São mundos que não se comunicam, representando uma dualidade de sistemas, sem um eixo unitário, o que prejudicaria profundamente a educação. Ou na assertiva de Fernando de Azevedo: "A educação teria de arrastar-se, através de todo o século XIX, inorganizada, anárquica, incessantemente dasagregada”. (AZEVEDO, 1975, p. 568).

Nesse contexto desagregador agravado pela falta de recursos, em que proliferam as aulas avulsas, são criados liceus provinciais, que passam a reunir essas aulas em um mesmo prédio. Nesse sentido, são criados o Atheneu Norte-Riograndense, em 1834, os liceus da Paraíba e da Bahia, em 1836, e em 1837, na cidade do Rio de Janeiro, é criado o Colégio Pedro II. Tal instituição, sob a jurisdição da Coroa, o que retoma a discussão da descentralização, estava destinada a servir de padrão ao ensino dos demais liceus do país: adotaria e manteria bons métodos, resistiria a inovações que não tivessem demonstrado bons resultados e combateria os espertos e charlatães, destinando-se à formação da elite intelectual. Sua importância era tamanha, pois era o único que fora autorizado a promover "exames parcelados para conferir o grau de bacharel, indispensável para o acesso aos cursos superiores" (RIBEIRO, 1993, p. 50).

Constata-se a preocupação do governo imperial com a formação dos filhos dos homens livres e a classe dirigente do país, preocupando-se com a criação dos cursos superiores e com as formas de acesso, registrando-se que um número bem reduzido cursava o secundário e conseguia chegar à universidade. Enquanto isso, a maioria da população continuava analfabeta, constituindo-se as leis educacionais que favoreciam essa maioria como letra morta, já que não eram colocadas em prática.

Atribuindo aos governos provinciais a responsabilidade pelo ensino primário e secundário, através de leis e decretos que na realidade não são postos em prática devido às precárias condições das províncias e aos interesses contraditórios que 
lá se processavam. Daí resultar o abandono da educação popular, o caráter propedêutico do ensino secundário, transformando a educação em mera ilustração e preparação para o exercício de funções, em que é privilegiada muito mais a retórica do que a criatividade.

Quanto ao ensino superior, a legislação determinava que era de responsabilidade do poder central, refletindo ser esse o nível que mais interessava ao poder político da época, pois eram os cursos superiores que formariam as elites dominantes, responsáveis pelo controle da sociedade. Ora, antes do período joanino, os estudantes brasileiros concluíam seus estudos nas instituições européias, principalmente em Coimbra, pois inexistiam cursos superiores no Brasil, à exceção dos seminários destinados à formação de padres.

Pelo Ato Adicional de 1834, constata-se a prerrogativa conferida ao ensino superior, que reforçava a característica classista da educação brasileira, "que privilegiava o acesso aos nobres, aos proprietários de terras e a uma camada intermediária, surgida da ampliação dos quadros administrativos e burocráticos" (ARANHA, 2006, p. 226), sendo os cursos jurídicos os que mais vão atrair os jovens brasileiros.

\section{Considerações Finais}

O descaso pela educação pública no Brasil independente é um fato que encontra explicação no contexto histórico e nas relações sociais, políticas e econômicas que se processavam no Império. As condições internas estavam postas para a efetivação da ruptura política. Porém, tal ruptura deu-se de maneira branda, comandada pelas forças dominantes, sem a participação popular, significando que os elementos de conservação da sociedade colonial brasileira continuariam ocupando o espaço que lhe pertencia por direito.

Ora, em uma sociedade agrária, escravocrata, aristocrática, autoritária e elitista a quem atenderia a educação? Certamente à elite dirigente, o que demonstra que a educação ofertada durante o Império e disciplinada na legislação do período, cumpria sua função, correspondendo às reais exigências da sociedade. Tal compreensão é decorrente da concepção de que o sistema econômico, a herança cultural e a demanda social por educação são fatores determinantes na organização e desenvolvimento do ensino.

Como já demonstrado, em uma sociedade como essa, inexistiam exigências originadas na economia. Já a herança cultural encontrava na Europa sua orientação, demandando por educação uma aristocracia ociosa e extratos das camadas médias urbanas, intensificando-se o preconceito contra o trabalho manual. Com fundamento nesse quadro, é cabível a afirmação de que a educação processada durante o Império articulava-se com as necessidades da sociedade.

Nesse sentido, centralização/descentralização dos atos do poder central, a ausência de escolas para o povo, o dualismo educacional, a defasagem entre a letra da lei e sua prática são características que só refletem as condições e interesses da sociedade brasileira no período imperial.

\section{Referências Bibliográficas}

ARANHA, Maria Lúcia de A. História da educação e da pedagogia: geral e Brasil. São Paulo; Moderna, 2006.

AZEVEDO, Fernando de. A cultura brasileira. São Paulo: Melhoramentos, 1975.

CARDOSO, Ciro F.; BRIGNOLI, Héctor P. Os métodos da história. Trad. de João Maia. Rio de Janeiro: Edições Graal, 1990.

CARDOSO, João Escobar J. O lugar do ensino de retórica nas reformas pombalinas da instrução pública. In: OLIVEIRA, Luiz Eduardo (Org.). A legislação pombalina sobre o ensino de línguas: suas implicações na legislação brasileira (1757-1827). Maceió: EDUFAL, 2010.

FEBVRE, Lucien. Combates pela história. Trad. Leonor M. Simões. Lisboa: Presença, 1977.

HOLANDA, Sérgio B. Raízes do Brasil. Rio de Janeiro: José Olímpio, 1991. 
MARTINS, V. Aspectos jurídico-educacionais da carta de 1824. Disponível em: http://www.ufsm. br/direito/artigos/constitucional/carta-1824.htm. Acesso em: 24 set. 2007.

MARTINS, Ana Luiza. Fontes para o patrimônio cultural: uma construção permanente. In: $\mathbf{O}$ historiador e suas fontes. São Paulo: Contexto, 2009.

NASCIMENTO, Maria Isabel M. et al. "Instituições escolares no Brasil colonial e imperial”. Disponível em : www.histedbr.fae.unicamp.br/navegando/artigos frames/artigo 075.html. Acesso: em 12/02/2009.
NOVAIS, Fernando. Portugal e Brasil na crise do antigo sistema colonial (1777-1808). São Paulo: Hucitec, 1986, p. 57.

OLIVEIRA, Luiz Eduardo. A invenção da tradição e o mito da modernidade. In: OLIVEIRA, Luiz Eduardo (Org.). A legislação pombalina sobre o ensino de línguas: suas implicações na legislação brasileira (1757-1827). Maceió: EDUFAL, 2010.

RIBEIRO, Maria Luísa S. História da educação brasileira: a organização escolar. Campinas, SP: Autores Associados, 1993.

\section{Sobre a autora}

Maria Elizete Guimarães Carvalho: Mestre e Doutora em Educação pela Universidade Federal do Rio Grande do Norte. Professora Adjunto III do Departamento de Fundamentação da Educação, Centro de Educação, da Universidade Federal da Paraíba. Pesquisadora do Grupo de Estudos e Pesquisas "História, Sociedade e Educação no Brasil" - HISTEDBR / GT - PB. Membro do Núcleo de Cidadania e Direitos Humanos da Universidade Federal da Paraíba - NCDH.

E-mail: mecarvalho23@yahoo.com.br 